\title{
Needle Free Injection
}

National Cancer Institute

\section{Source}

National Cancer Institute. Needle Free Injection. NCI Thesaurus. Code C100050.

A drug delivery system that permits injection of a liquid medication subcutaneously without the use of a needle. 